2-7-2013

\title{
Urban Forest Justice and the Rights to Wild Foods, Medicines, and Materials in the City
}

Melissa R. Poe

Northwest Sustainability Institute

Rebecca J. McLain

Portland State University

Marla R. Emery

USDA Forest Service

Patrick T. Hurley

Ursinus College,phurley@ursinus.edu

Follow this and additional works at: https://digitalcommons.ursinus.edu/environment_fac

Part of the Demography, Population, and Ecology Commons, Environmental Policy Commons, Environmental Studies Commons, Nature and Society Relations Commons, Other Political Science Commons, Place and Environment Commons, and the Urban Studies and Planning Commons Click here to let us know how access to this document benefits you.

\section{Recommended Citation}

Poe, Melissa R.; McLain, Rebecca J.; Emery, Marla R.; and Hurley, Patrick T., "Urban Forest Justice and the Rights to Wild Foods, Medicines, and Materials in the City" (2013). Environmental Studies Faculty Publications. 8.

https://digitalcommons.ursinus.edu/environment_fac/8 


\title{
Urban Forest Justice and the Rights to Wild Foods, Medicines, and Materials in the City
}

\author{
Melissa R. Poe • Rebecca J. McLain • Marla Emery • \\ Patrick T. Hurley \\ Published online: 7 February 2013 \\ (C) Springer Science+Business Media New York (outside the USA) 2013
}

\begin{abstract}
Urban forests are multifunctional socio-ecological landscapes, yet some of their social benefits remain poorly understood. This paper draws on ethnographic evidence from Seattle, Washington to demonstrate that urban forests contain nontimber forest products that contribute a variety of wild foods, medicines, and materials for the wellbeing of urban residents. We show that gathering wild plants and fungi in urban forests is a persistent subsistence and livelihood practice that provides sociocultural and material benefits to city residents, and creates opportunities for connecting with nature and enhancing social ties. We suggest that an orientation toward human-nature interactions in cities that conceptualizes the gathering of forest products as a legitimate social benefit may support and expand urban forest justice. Urban forest justice recognizes the rights of local people to have control over their own culturally appropriate wild food and health systems, including access to natural resources and to the decision-making processes affecting them.
\end{abstract}

Keywords Urban foraging · Forest justice · Urban ecosystems $\cdot$ NTFPs $\cdot$ Social benefits

\section{Introduction}

Urban forests are socially and ecologically diverse, multifunctional landscapes (Alberti et al. 2003). Ecological research on urban ecosystems highlights the importance of urban forests

M. R. Poe $(\bowtie)$

Northwest Sustainability Institute, Seattle, WA, USA

e-mail: melissarpoe@gmail.com

R. J. McLain

Institute for Culture and Ecology, Portland, OR, USA

M. Emery

USDA Northern Research Station, Burlington, VT, USA

P. T. Hurley

Ursinus College, Collegeville, PA, USA in ameliorating air temperatures (Simpson 1998), sequestering carbon and other air pollutants (Nowack et al. 2006), reducing storm water run-off (Xiao et al. 1998), and providing habitat for wildlife (Melles et al. 2003). Conservation science, Sanderson and Huron (2011: 422) argue, should not only aim to conserve and restore these spaces, but also "work to create the presence of diverse, functional ecosystems that are self-sustaining and sustain humans as part of them."

How do urban forests ${ }^{1}$ sustain humans? Social scientists have found that urban forests and greenspaces improve mental well-being (Hull 1992; Kaplan 1995), lower crime rates (Kuo and Sullivan 2001), enhance social cohesion (Kuo 2003), and promote community empowerment (Westphal 2003); these contributions, however, are not necessarily experienced equally (Jennings et al. 2012). Economic studies indicate that the presence of trees is associated with higher property values (Donovan and Butry 2010) and higher rates of spending in business districts (Wolf 2009). Much less attention has been paid to urban forests as providers of tangible forest products (Dobbs et al. 2011).

Research on urban nontimber forest product (NTFP) gathering is quite limited (McLain et al. 2012a). Exceptions include Jahnige's (2002) exploratory work cataloguing the range of NTFP gathering in Baltimore, Maryland, and Konijnendijk's (2008) review of the history of urban forests as sources of goods and cultural services for European city dwellers. Also important is Terada et al.'s (2010) research on Tokyo, Japan's satoyama forests, in which fuel wood harvesting is identified as a necessary element for the proper functioning of the system. And in New Zealand, Wehi and Wehi (2009) discuss how

\footnotetext{
${ }^{1}$ We use the definition provided by the 1978 U.S. Cooperative Forestry Assistance Act, which defines urban forests as "trees and associated plants, individually, in small groups, or under forest conditions within cities, their suburbs, and towns." Following this definition, urban forests include all trees, associated understory vegetation, and fungi in urban areas on private and public land. This definition also includes trees and other plants historically or ornamentally cultivated, which may be found in diverse spaces such as natural areas, street edges, parks, and vacant lots.
} 
Maori elders' traditional harvesting in urban areas reduced pressure on species in non-urban conservation areas; there, urban harvesting also helped maintain indigenous cultural practices and local ecological knowledge. However, research on an expanding informal commercial wild harvesting market in and around Cape Town, South Africa by an influx of (formerly rural) domestic migrants and refugees raised awareness of the potentially negative impact intensified NTFP commercial harvesting could have on ecological sustainability, especially for threatened species, in cities (Petersen et al. 2012).

In this article, we examine contemporary urban NTFP gathering in Seattle, Washington to show that items such as wild berries, weeds, edible mushrooms, and fallen branches contribute to many urban residents' lives by supporting subsistence, cultural practices, and enhancing quality of life. Gathering NTFPs from urban forests also creates powerful connections between urban residents and natural cycles. People gather NTFPs from a variety of urban habitats (e.g., forested parks, street edges, alleyways, play fields, campuses and sidewalks, etc.). Urban NTFPs include entire plants, plant parts (e.g., seeds, cones, leaves, flowers, and fruits) and plant exudates, as well as fungi, mosses, and lichens. We also include honey and wood products other than timber (e.g., firewood, poles, and specialty woods for crafts) in our definition of NTFPs, but exclude from consideration animals, fish, shellfish, or insects.

Persistence and significance of urban plant and mushroom gathering notwithstanding, the social benefits of urban NTFPs remain largely unrecognized by professional conservation communities (McLain et al. 2012b). When they discuss them at all, urban foresters viewed NTFPs such as leaves, branches, and fruit as costs rather than benefits (see Barker 1986; McPherson et al. 2005). Moreover, many municipalities and urban planners reject deriving products as a legitimate function of urban forests (McLain et al. 2012b). This raises a number of social justice concerns not unique to our case study: namely, who has access to the natural resources in the city, for what purposes, and who participates in the decision-making that shapes priorities, policies, and planning in public and quasi-public urban ecosystems?

Urban forests provide goods derived from plants and fungi to support wild foods, medicines, livelihoods, and other sociocultural values and needs. Applying insights from political ecology and the food and health justice literatures to our study of urban NTFP gathering, we develop an 'urban forest justice' framework. An urban forest justice framework, we suggest, recognizes the rights of urban people to control their own culturally appropriate food and health systems based in cultures of gathering wild edible and medicinal plants and fungi.

\section{Urban Forest Justice Framework}

Our work sits at the intersection of three literatures: (1) political ecology treatments of rural forest justice and urban social-ecological systems; (2) food justice and sovereignty within environmental justice; and (3) the emerging subfield of health justice and sovereignty. This paper contributes to these literatures in two key ways. First, it opens the forest justice field, which has mostly focused on rural contexts, to an examination of forest environments in postindustrial urban contexts, where cosmopolitan communities and their respective nature practices are often highly diverse. Second, it expands the focus of productive activities and spaces under examination in the food and health justice literatures (which have mostly focused on gardens, farms, and central dispensaries) by adding a focus on foods and medicines wild-harvested from urban environments.

Drawing insights from these literatures, we outline three dimensions of an urban forest justice analysis: (1) equitable access to urban forest resources and benefits; (2) participation of gatherers in decision-making about how urban forests are managed; and (3) recognition of the fundamental ways that cultural identities, livelihoods, and social relations are embedded in urban forest systems provisioning wild goods.

\section{Forest Justice: Lessons From Political Ecology}

Political ecologists have examined the political economic dimensions of ecological problems and how these impact social actors differently across socio-economic differences, and geographic spaces and scales (Blaikie and Brookfield 1987; Bryant and Bailey 1997). Not simply concerned with the problems of land degradation and natural hazards, political ecology has examined the ways that scientific ideologies, state agencies, power dynamics within and among institutions, and group micropolitics influence people's rights and access to natural resources and the management thereof (Paulson et al. 2005; Peet et al. 2011; Robbins 2012). Political ecologists pay close attention to the ways that social relations and situated knowledge - often linked to class, race, and gender - shape views about environments and create inclusionary or exclusionary engagements with nature (Brosius et al. 2005; Rocheleau 2008).

This research reveals the politics that shape forest-related natural resource use and access in rural areas. Forests become sites of contestation where particular resource extraction practices, ranging from tree-felling to petty forms of theft, are condoned while others are criminalized (Klooster 2000; Peluso and Vandergeest 2001). Contestations often emerge between long-time users and professional managers who draw on sometimes problematic tenets of scientific forestry to determine harvest levels and types (Hecht and Cockburn 1990; Peluso 1992). These struggles can play out negatively for those whose livelihood uses are delegitimized by dominant management schemes (Kosek 2006) and can make access to the flow of benefits from forests unequal 
(Ribot and Peluso 2003). Government and quasigovernment agency decisions about which forms of natural resource management to pursue may change the composition of forests, leading to detrimental effects on particular communities that depend on forest product harvests (Schroeder 1999). Observing these forest politics repeat across many rural and international spaces, some social scientists have begun to outline a rights-based agenda grounded in international law to guide a social justice approach to forestry and research (Sikor 2010; Zerner 1999). Sikor and Stahl (2011) propose that equitable distribution of forest benefits, recognition of forest based cultures and identities, and participation in forest governance promote forest justice.

In urban contexts, political ecologists have begun documenting the ways that political-economic structures and processes affect who benefits from nature and its management in the city (Byrne and Wolch 2009; Dooling 2009; Heynen 2003; Jennings et al. 2012). Drawing on this work, we note that barring access to gathering in urban forests in favor of passive amenities, recreational uses, and other narrowly defined restoration and stewardship activities, privileges particular values and services of, and practices with, nature in the city. Moreover, as some scholars note, it also serves to privilege certain species and configurations of urban green spaces with distinct socio-economic implications (Brownlow 2005). For example, research from South Carolina on sweetgrass (Muhlenbergia sericea) basketmaking points out the ways that long-time resource users can influence vegetation management in ways that facilitate continued access to raw materials, including through the formation of social networks with private landowners in residential and commercial landscaping spaces (Grabbatin et al. 2011).

\section{Food Justice and Sovereignty}

While the emerging food justice scholarship argues similarly for more equitable access to resources and participation in decision-making, its emphasis on the cultural importance of food pushes us to think about the social relationships, cultural meanings and exercise of rights produced through practices across food systems (Alkon and Agyeman 2011). Moreover, in contrast to a narrower focus on food security (simply having enough food), the food justice and sovereignty scholarship examines political-economic dimensions of control over food resources, for example, by scrutinizing the ways that food production, distribution, and consumption reproduce racial and economic inequalities, and by exploring the possibilities for productive autonomy by local communities independent of capitalist food economies (Alkon and Mares 2012; Whitman 2011). Examples of such possibilities include the emergence of "slow food" movements and "100 mile diets" (e.g. Nabhan 2006), and indigenous foods movements (e.g. B.C. Food Systems n.d.; Northwest Indian College n.d.). Localizing food production can be seen as an alternative response to neoliberal and colonialist food economies that have created socially and environmentally-costly externalities (Alkon and Mares 2012; Emery et al. 2006; Guthman 2008; McMichael 2009).

As a lens applied to wild harvesting, food justice recognizes the rights of local people to have control over their own culturally appropriate wild and place-based food systems, including access to resources and to the decisionmaking processes affecting spaces with wild goods. Furthermore, when applied to wild foods, ${ }^{2}$ a justice perspective recognizes the fundamental ways that diverse cultural identities and social relations are embedded in gathering practices. This observation is particularly significant in socio-economically diverse cities, in areas with colonial histories of indigenous displacement and trauma, and where indigenous and other longstanding livelihoodbased users seek access to natural resources to support cultural revitalization and a deeply historic struggle for food sovereignty (Adamson 2011; Cardinal 2006; Middleton 2010; Salmón 2012; Wilkinson 2000).

\section{Health Justice and Sovereignty}

Related scholarship examining health justice and sovereignty provides an important link for thinking about the intersection of food justice and health practices. Traditional medicinal plant practices have been documented in urban contexts by a small number of ethnoecologists (Balick and Lee 2001; Ceuterick et al. 2008; Hodges and Bennett 2006). These studies have shown the linkages between urban medicinal plant use, the retention of traditional ecological knowledge, the maintenance of cultural ties, the utilitarian and symbolic-cultural aspects of folk medicine for urban groups, and the important role herbal medicine shops play in a region's health care system. However, these studies primarily examine purchased and imported plant remedies, not in situ practices of local medicine wildcrafting and gathering.

Other studies on the health effects of urban gardens and parks indicate that being in the presence of plants and interacting with plants can positively affect mood, stress

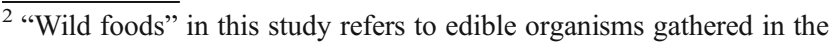
wild. These may come from native or introduced species, and grow naturally or opportunistically in associated habitats. Wild foods may come from tended or cultivated species, but which are not intentionally planted or maintained for agricultural food production. This may include "weeds", ornamental species in landscaped areas, and remnant plants (e.g., from trees of former orchards subdivided into newer urban lots.) For a discussion on challenges in defining "wild foods", see Bharucha and Pretty (2010).
} 
levels, self-esteem, and ability to focus (Hull 1992; Kaplan 1995; Söderback et al. 2004). Yet, these studies overlook plant and mushroom gathering as an interactive humannature practice. Medicinal use of wild plants and fungi may also be important for addressing primary health and nutrition needs, especially in areas where political, economic and environmental changes may threaten health resiliency and wellbeing (Loring and Gerlach 2009). Wild foods may improve nutrition (Kuhnlein and Turner 1991); moreover, these foods may reduce diabetes and stress-related illnesses, and the practice of gathering may also increase connections to traditional foodways and diverse healing practices (Bruyere 2006; Krohn and Segrest 2010; Samson and Pretty 2006; Wilson 2003). The practice of wild medicine and its interconnections with culture, knowledge, practice, access, and environmental health is particularly important in areas of increased vulnerabilities. For example, Kassam et al. (2010), address the importance of wild medicines in Central Asia where war, poverty and industrialization have had deleterious impacts on these mountain communities. Similarly, Adelson (2000: 3) notes in her critical study of health and well-being of the northern Cree indigenous communities in Canada, "health has as much to do with social relations, land, and cultural identity as it does with individual physiology."

Like food sovereignty, the focus on health justice when applied to urban wild harvesting recognizes the rights of local people to control their culturally appropriate health systems, including recognition and accommodation of culturally diverse wild medicine practices and the systems upon which they depend. Maintaining the support for culturally diverse and relevant wild medicine practices is not only an issue of health justice, it's also an issue of how we govern people and ecosystems, even in urban areas.

\section{Study Area and Methods}

The City of Seattle, with a population of 612,000 (OFM 2010), is located in Western Washington State and has a land area of roughly 84 mile $^{2}$ (54,000 acres). Seattle and the surrounding region are places where people have gathered wild foods since long before European settlement and where both native and non-native communities continue to do so today (Thrush 2007; McLain et al. 2012b; Turner 1995). The city's mild climate, long growing season, and historic land uses favor diverse vegetation types: dominant secondgrowth hardwood forests (primarily bigleaf maple (Acer macrophyllum Pursh) and red alder (Alnus rubra Bong.); remnants of old-growth western marine lowland forest (western hemlock (T. heterophylla (Raf.) Sarg.), western red cedar (Thuja plicata Donn ex D. Don), and Douglas-fir (Pseudotsuga menziesii (Mirb.) Franco); and heterogeneous urbanized landscape patches with a diversity of understory plant and fungal species (Jacobson 2008; McLain et al. 2012b).

Seattle's population, like many U.S. cities, has a diverse racial and ethnic composition: $69.5 \%$ white, $13.8 \%$ Asian, $8 \%$ African American, $0.8 \%$ Native American, $0.4 \%$ Native Hawaiian or other Pacific Islander, $2.4 \%$ from other races, and $5.1 \%$ two or more races. Self-identified Latino and Hispanic residents account for $6.6 \%$ of the population (US Census 2010). Foreign-born residents made up $17.3 \%$ of the city's population in 2009 (City of Seattle 2009). Recent surveys found that $14.4 \%$ of the area's households experienced food hardship in 2010 (Food Research and Action Center 2011), an indicator that the need to access food resources is greater than ever (Garrett et al. 2006).

\section{Methodology}

This paper draws from 2 years of ethnographic research on urban NTFP gathering in Seattle. Ethnographic methods have proven to be particularly effective for studying everyday human interactions with plants and for identifying the range of individual and cultural meanings, values, and norms associated with particular plants and types of landscapes (Grove et al. 2006; Kinzig et al. 2005). We conducted 76 semi-structured interviews with 58 adult gatherers and 18 conservation leaders using a purposive sampling strategy. We used a multi-pronged strategy to identify potential gatherers: flyers and invitations to participate in a number of botanical shops, garden centers, and other visible community networks (e.g. permaculture, native plant and mushrooms clubs, and basket weaving guilds); announcements in diverse media outlets (e.g. social media and online newsletters); and snowball sampling.

Semi-structured interviews combined standardized openended and demographic questions. Questions were designed to elicit information about gatherers' use of plants and fungi, the reasons for harvesting, ways gatherers learned to identify and use species and related knowledge, locations where harvesting takes place, the ways gatherers access resources, steps taken to steward resources, social interactions, barriers encountered, and demographic information. Interviews, conducted in English, lasted approximately $1 \mathrm{~h}$ and a half; each interview was audio-recorded and transcribed.

We triangulated interview data with participant observation in field forays with adult and child practitioners and through attendance at public meetings where plant activities, urban food, and forest activities were discussed. Participant observation enabled us to overcome some potential barriers presented by interviewing procedures alone; these included: concerns regarding visibility and retribution, time commitments, language barriers, and distress around formal research protocols. Each of these participant observation 
events were documented in detailed field notes and constitute part of the ethnographic dataset. Data was systematically analyzed using qualitative data analysis software.

\section{Results: Gathering in Seattle's Urban Forest}

\section{A Community of Practice}

We use the terms "gatherer", "forager" and "harvester" interchangeably to describe individuals who, although heterogeneous in their activities, cultures, and motivations, comprise a group linked through common interests, knowledges, and practices based in gathering parts from plants and mushrooms. Following the findings of Robbins et al. (2008), rather than develop a typology of gatherers differentiated by socio-demographic characteristics, we frame gatherers here as a "community of practice" that exists in parallel distinction to other urban forest communities of practice, such as birders, restorationists, sport players, land managers, and homeowners.

Gatherers are diverse and include life-long Seattle residents (both indigenous and non- indigenous) as well as domestic and international immigrants. The annual incomes of gatherers ranges from less than 20,000 USD to over 100,000 USD. Their ages range from childhood to over 80 years; the average in this study is 44 . Some gatherers are new to the activity (within the past 2 years), while others have foraged in Seattle for over 60 years. The average length of time interviewees in our study have been gathering is 24 years. While we did not formally interview children, children excitedly foraged during participant observation events. Additionally, many of the long-time foragers we interviewed described gathering with parents and grandparents during childhood and several described collecting plants and mushrooms with their own children, indicating that foraging is an intergenerational and traditional practice.

\section{Gathering Practices}

We define gathering as a practice that involves the removal of fungi, plants, or parts of plants with the intention of using the materials gathered for foods, medicines, crafts, fuel, ceremony, decoration, or exchange. Following Deur (2002) and Ford (1985), we see gathering as existing along a continuum of human-plant production interactions with gathering on one end, tending in the middle, and cultivation of domestic plants on the other end. We recognize that the boundaries between these categories are fuzzy, and that in urban forest ecosystems in particular gathering may well involve harvesting products from plants intentionally planted or cultivated by others. Figure 1 gives examples of where different types of human-plant interactions might be located along the gatherer-tender-cultivator continuum.

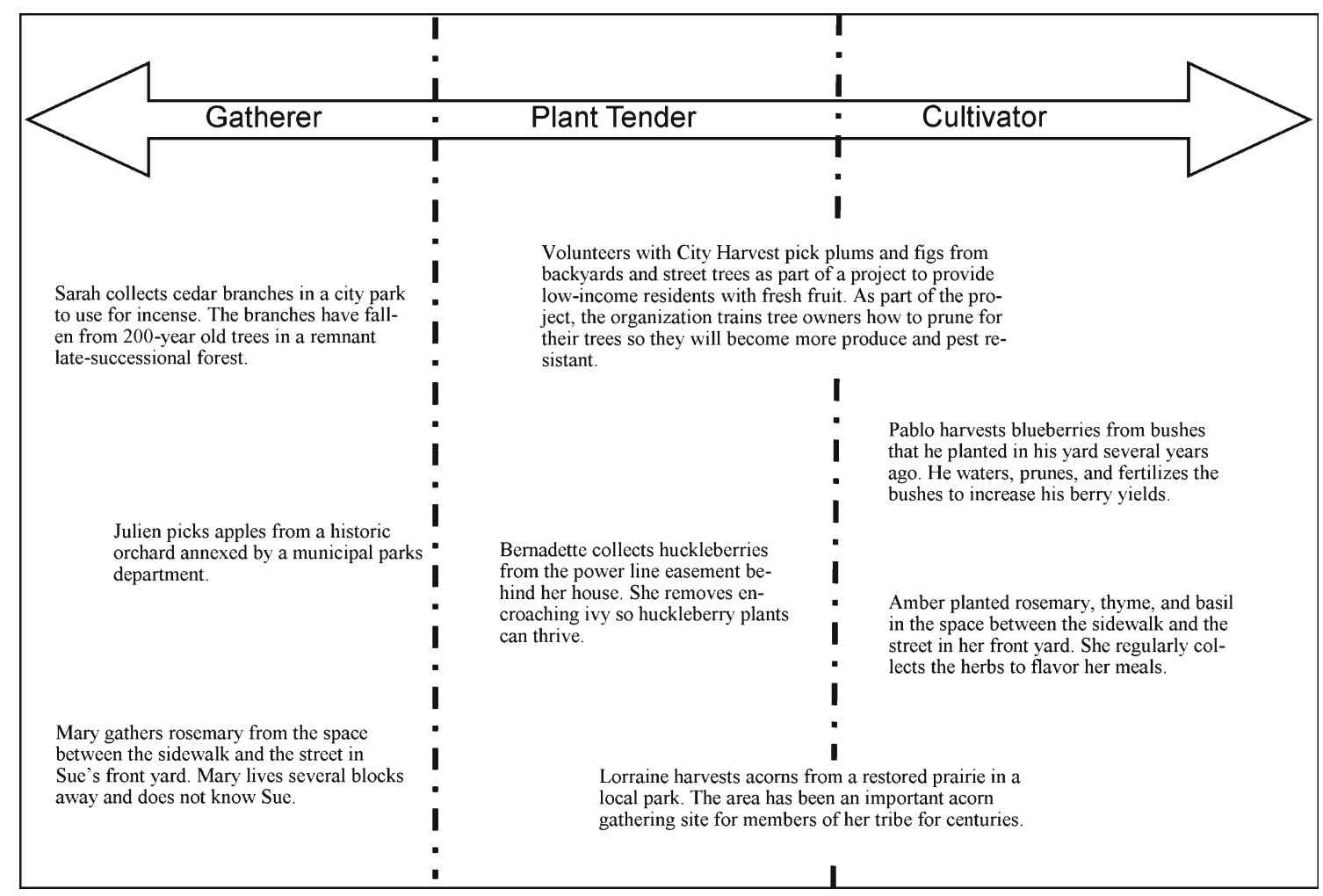

Fig. 1 Activities along the gatherer-cultivator continuum 
Leaves, fruits, seeds, pollen, branches, bark, cones, buds, flowers, sap, stems, shoots, roots and tubers from a large number of species are gathered in Seattle, indicating the presence of a rich biocultural diversity in the city. Interviewees reported gathering parts from 486 species (433 plants and 53 fungi, see Tables 1 and 2 for commonly gathered species). While some species are preferred nearly universally (e.g., Himalayan blackberry), others constitute culturally distinct species preferences such as: salmonberry and nettle for Coast Salish communities; chestnuts, watercress, pennywort and plantain for Korean, Hmong, Vietnamese and Cambodian gatherers; hawthorn fruit for Eastern European collectors; amaranth for Mexican households; plums and various types of mushrooms for Russian gatherers. Study participants who identify as part of the urban American Indian/Alaska Native community conveyed feelings of disconnection and lack of access to culturally important plants (e.g., elderberry and camas). These access issues may have as much to do with the social complexities of urban indigenous people, many of whom come from places quite unlike Seattle, as they do with colonial settlement, displacement or contemporary land management (cf. Cardinal 2006).

People forage year round in Seattle. Spring, summer, and fall are more active harvesting times owing to species availability. However, winter also offers gathering opportunities including residual berries and edible weedy greens. Winter storms bring down potentially useful branches, boughs and cones. Seasonal variation also impacts the amount of time people spend gathering and processing plants and mushrooms.

Urban gatherers often possess sophisticated local ecological knowledge, including: species identification; species assemblages, composition and distribution; soil conditions; subtle seasonal shifts; and year-to-year changes in plant composition and productivity. People learn and pass on information about gathering in many ways, including: through family and friends; formal botany, ethnobotany, herbalism, and mycology instruction; and field guides and books. Many study participants are actively engaged in teaching others about plant and mushroom identification, harvesting, and processing through both formal programs and informal one-on-one field excursions. Knowledge transfer is essential to preserving gathering practices and sharing information about safe ways to identify, harvest and process edible and medicinal species. As some species may be toxic to humans, this knowledge is essential. For example, poison hemlock grows in Seattle, and many foragers will avoid plants in the same family (Apiaceae) to reduce chances of exposure to this dangerously toxic species. Similar caution is applied in mushroom identification. Apart from one interviewee who had once accidentally put the toxic (and

Table 1 Salient plants gathered in Seattle

\begin{tabular}{|c|c|c|c|}
\hline Latin Name & Common Name & Uses & Parts used \\
\hline Castanea sativa & European Chestnut & Food & Nuts \\
\hline Gaultheria shallon & Salal & Food, medicine, floral & Fruit, branches, leaves \\
\hline Lavandula spp. & Lavender & $\begin{array}{l}\text { Food, medicine, skin care, } \\
\text { ceremony, decoration }\end{array}$ & Leaves, blossoms, whole plant \\
\hline Mahonia nervosa & Low or dull Oregon Grape & Food, medicine, dye & Fruits, bark, roots, stems, tender leaves \\
\hline Mahonia aquifolium & Tall Oregon Grape & Food, medicine, dye & Fruits, bark, roots, stems, flowers, tender leaves \\
\hline Malus domestica & Apple & Food, cider, soap, incense & Fruit, branch, bark \\
\hline $\begin{array}{l}\text { Populus balsamifera } \\
\text { spp.trichocarpa }\end{array}$ & $\begin{array}{l}\text { Black cottonwood, western } \\
\text { balsam poplar }\end{array}$ & Food, medicine, construction & Catkins, cambium, buds, bark, shoots \\
\hline Prunus domestica & European plum & Food & Fruit, branches \\
\hline Pyrus communis & European pear & Food & Fruit \\
\hline Rosa nutkana & Nootka rose & Food, tea & Hips, petals, roots, bark, stems \\
\hline Rosmarinus officinalis & Rosemary & $\begin{array}{l}\text { Food, medicine, tea, } \\
\text { decoration, spiritual }\end{array}$ & Leaves, blossoms, whole plant \\
\hline Rubus armeniacus & Himalayan blackberry & Food; weaving, fencing & Fruit, stems \\
\hline Rubus laciniatus & Evergreen blackberry & Food & Fruit \\
\hline Rubus spectabilis & Salmonberry & Food & Fruit, young shoots, blossom \\
\hline Rubus parviflorus & Thimbleberry & Food & Fruit, young shoots \\
\hline Taraxacum officinale & Dandelion & Food, medicine & Leaves, flowers, roots \\
\hline Thuja plicata & Western red cedar & Craft, basketry; medicine, spiritual & Bark, leaves, wood, sap, needles \\
\hline Typha latifolia & Cattail, bulrush & Food; medicine; fiber & $\begin{array}{l}\text { Rhizome, stalk, roots, pollen, immature } \\
\text { flower spikes, leaves }\end{array}$ \\
\hline Urtica dioica & Stinging nettle & Food; medicine; cordage & Young leaves, root, stems, seeds, stalk \\
\hline Vaccinium parvifolium & Red huckleberry & Food & Fruit \\
\hline
\end{tabular}


Table 2 Salient Fungi and lichens gathered in Seattle

\begin{tabular}{|c|c|c|}
\hline Latin Name & Common name & Uses \\
\hline Agaricus augustus & The prince & Food, choice edible \\
\hline Boletus edulis & King bolete; porcini & Food \\
\hline Calvatia gigantea & Giant puffball & Food \\
\hline Cantharellus spp. & Chanterelle & Food \\
\hline Chlorophyllum rhacodes (Lepiota rachodes) & Shaggy parasol & Food, edible with caution \\
\hline Coprinus comatus & Shaggy mane; inky cap & Edible when young, dye \\
\hline Evernia spp. & Lichen & Dye \\
\hline Ganoderma applanatum (Polyporus applanatus) & $\begin{array}{l}\text { Artist conk, giant shelf fungus, } \\
\text { kofukitake (Japanese) }\end{array}$ & Art, sculpture, paper, mycorestoration \\
\hline Ganoderma oregonense & Varnish conk & Medicine \\
\hline Hypomyces lactifluorum & Lobster mushroom & Food, dye \\
\hline Lactarius rubidus (L. fragilis var. rubidus) & Candy cap & Food \\
\hline Laetiporus conifericola & Chicken of the Woods & Food \\
\hline Leccinum scabrum & Birch bolete & Food \\
\hline Lepista nuda & Blewit & Food \\
\hline Morchella spp. & Morel (commonly, "landscape morel") & Food \\
\hline Pleurotus ostreatus & Oyster mushroom, hiratake, tamogitake & Food; mycorestoration \\
\hline Psilocybe cyanescens & $\begin{array}{l}\text { Potent psilocybe, cyan, caramel cap, } \\
\text { magic mushroom, wavy cap }\end{array}$ & Medicine, mind altering \\
\hline Ramalina spp. & Lichen & Dye \\
\hline Trametes versicolor & Turkey tail polypore fungus & Medicine, paper \\
\hline Usnea filipendula & Beard lichen & Medicine \\
\hline
\end{tabular}

medicinal) plant foxglove in his mouth and then quickly spit it out to no ill-effect, gatherers in our study reported no incidence of poisoning from wild plants or mushrooms, and took great care to avoid such cases.

Most gatherers in this study voiced strong environmental stewardship ethics and a commitment to sustainable harvesting techniques. For example, gatherers often make choices about plant species, parts of organisms, and quantities harvested based on their understanding of sustainable practices. They may consider factors such as relative species abundance, plant status as "native" or "invasive", reproductive characteristics, available forage for valued wildlife, and the plant's role in habitat conservation. Gatherers often tend plants and harvest in ways to ensure their vigor and abundance, as well as to preserve resources for other users.

\section{Gathering Spaces}

Ecological patterns, land-use histories, resource tenure, and environmental management shape biological diversity and gatherers' access to valued species. Gathering sites are ecologically and spatially heterogeneous and might be located in private, public, and quasi-public, de facto commons, or open access property arrangements. These spaces include: parks, wooded forests, yards, sidewalks, historic orchards, planting strips on street edges, institutional campuses, alleys, cemeteries, trails, landscaping areas, empty lots, and abandoned properties. Seattle's municipal code prohibits removing any plant part from city parks. ${ }^{3}$ However, public tree fruit harvesting and stewardship programs emerging throughout the city in public park spaces, signal a shift in official policies toward harvesting in urban forests (McLain et al. 2012b).

Interviewees described avoiding some species from spaces that might be more susceptible to pollution; for example, edible oyster mushrooms may take up toxins in contaminated soils (Stamets 2005). Watercress from unknown watersheds and edible seaweeds found along the shores of Seattle are mostly avoided because they are believed to be especially prone to concentrate pollutants from run-off. Public information about soil contamination is rarely available. Moreover, chemical herbicides are used by public and private gardeners to eradicate many choice edibles (e.g., dandelion and knotweed). Seattle parks crews have posted notices when these toxins are applied, and the city is beginning to list parks managed without toxic chemicals on public

\footnotetext{
${ }^{3}$ The code states: "It is unlawful for any person except a duly authorized Department of Parks and Recreation or other City employee in the performance of his or her duties, or other person duly authorized pursuant to law, to remove, destroy, mutilate or deface any ... shrub, tree, ... plant, flower, ... in any park." (SMC 18.12.070)
} 
websites. Gatherers consider land use (current and past) in their decisions about site selection to reduce risk of exposure to harmful pollution. For example, former industrial zones and railroads are generally avoided.

\section{Social Benefits and Values of Urban Gathering}

People gather urban NTFPs primarily for personal use, and motivations are multifold, including important material and non-material purposes. Ninety-five percent of the gatherers (out of 58 interviewed) collect plants and mushrooms for household food uses, $55 \%$ indicated gathering for medicinal purposes, $40 \%$ collect for craft materials, $16 \%$ for fuel (firewood and biofuel), and fewer than $10 \%$ gather for plant salvage, construction, or science and taxonomic purposes (see Table 3). As well, gatherers are motivated by many non-material purposes: maintaining cultural practices, sharing knowledge, building community, engaging in spiritual practices, connecting with nature, supporting stewardship, having fun and recreating, and developing alternative food and health systems.

\section{Wild Foods}

Food is the most basic reason people gather in Seattle, but food practices are nonetheless complex. Self-provisioning with wild foods is regarded as fun, nutritious, resourceful, empowering, and, in many cases, connected to tradition and cultural identities. The importance of gathering food in the city is often rooted in overlapping values.

For many foragers wild foods are part of an economic strategy to bridge food needs and extend budgets. For example, one single mother derived $25 \%$ of her food from urban foraged goods, and another forager recounted, "I seriously didn't have any money for food. I would go out and try to look for anything ... I wished for an apple tree or something. Because man, that would have been so great, when you're 2 days before your pay check and you just got nothing." As well as closing the food gap on a family

Table 3 Material motivations for urban foraging

\begin{tabular}{lll}
\hline Material Purpose & $\begin{array}{l}\text { Number of } \\
\text { Foragers indicating } \\
\text { this purpose }\end{array}$ & $\begin{array}{l}\text { Percentage of } \\
\text { total (no =58) }\end{array}$ \\
\hline Food & 55 & 95 \\
Medicine & 32 & 55 \\
Arts and crafts & 23 & 40 \\
Fuel (firewood, etc.) & 9 & 16 \\
Plant salvage, propagation & 4 & 7 \\
Construction, materials & 3 & 5 \\
Science, taxonomy & 2 & 3 \\
\hline
\end{tabular}

subsistence level, some foragers collected wild foods for other people who may be food insecure but who do not themselves gather. For example, one interviewee who organizes an informal neighborhood gleaning effort described gathering and donating a few hundred pounds of fruit to a neighborhood church and food bank, in addition to the hundred pounds he collected annually for his own household. Formal community gleaning projects gathered over forty-five thousand pounds of tree fruit for local foods banks between 2009 and 2012 (personal communication with City Fruit, see also McLain et al. 2012b).

Gathering is a way that foragers assert their rights to subsistence and to informal economic activities that involve non-capitalist exchanges. Speaking about why she gathers, one participant commented, "Because it's our right. Our bodies are our right, and nature is our right, and we can't just be a consumer of the commercial world." Several foragers expressed similar convictions about the right to wild foods. For example, reflecting on a scenario that would prevent him from gathering, one said,

If I'm out hiking or just taking a walk and something is edible and beckoning to me and I can't do this, I can't eat it, that goes against my experience of decades and it's not something that would sit well with me. It would be like part of me is put in jail. I'd feel deprived and I would be actively plotting to change that. If I couldn't change the law or the prohibition, I would probably defy it. And if I couldn't defy it, I would be frustrated and malcontent. It would be significant.

Speaking similarly about the political rights to gather food, another forager commented,

I am looking to get more connected with where my food comes from. I think that's what is going to heal our society, heal our relationships, and heal the earth. That's part of my goal, as to why I harvest my own stuff. The other reason why I harvest is kind of more political. Believe it or not. When someone controls your food source, they control you. You want to control a population, you control their food source. And that's what big industry does ... As an active political revolt, the most important thing I can do is become sustainable, is to become self-sufficient ... I don't want to be controlled. I don't want the government telling me what I can and cannot eat.

Reducing food waste and "food miles" also motivates many foragers. Many foragers found difficulty in passing up perfectly edible products hanging on trees or decaying on the ground: "It's really hard to walk away when you know that those are just going to fall on the ground and 
rot. It just kind of drives me nuts!" Some gather explicitly for environmental sustainability reasons, including eating from ultra-local sources. For such "locavores", it doesn't get much more local than weeds from the yard or mushrooms around the block:

I'm really intrigued by the fact that there's so many readily available food sources right in our area and if people only knew this, and there's no shipping involved, for most of these I can walk to it, and I grow my own garden as well, and just try to minimize my impact on the earth and collecting local foods is one of the best ways you can do it.

In many cases, people gather wild food because it is tied to their cultural and family traditions. This is true for indigenous gatherers, non-indigenous gatherers who settled the Pacific Northwest generations ago, and newcomers alike. For example, one study participant who is Alaska Native and currently homeless, described gathering wild berries along a trail in the city. $\mathrm{He}$ ate some himself and gave away the rest, owing to his inability to store food. He also gathered driftwood from area beaches, singing traditional songs as he did so. He used the wood to carve spirit masks in the tradition of his home community in central Alaska, which he sold to help make a little money. Another gatherer, a EuropeanAmerican basketmaker and food wildcrafter in her early fifties, reflects on the importance of foraging in her family's traditions:

I grew up in the Northwest. I grew up with parents who are teachers and my dad was a primary income maker in the household. So one teacher's budget, three kids, you know our vacations were out camping. They were out camping for going fishing, ... shellfish and oyster harvesting, ... berry harvesting was always a big one. So I think it was really instilled upon me when I was very young that the earth takes care of our needs.

Likewise, another forager who 6 years prior had immigrated with her family to Seattle from Moscow described her urban foraging as "a piece of our culture." She continued, "back in Russia we were living so close to nature, to forests. We always - I think historically — gathered food in the forest. It was considered normal."

\section{Wild Medicines}

The second most common reason people forage in Seattle is to gather wild medicines. Gatherers commented on five main health and wellness benefits: nutrition, herbal medicine, local access, health empowerment, and spiritual wellness. The overall health benefits of wild foods consumption may have tremendous benefit to daily life, a point illustrated here:

I really attribute a lot of my health to wild foods. I used to be fairly sickly and now I have really strong, vibrant health, and have for a long time. I feel like what kind of helped me over that hump was the wild foods. I would just do nettle and oat straw infusions every day and [wild foods] really helped build up my core vitality that I was missing.

Many species gathered and eaten by study participants are nutrient rich (Kuhnlein and Turner 1991). Herbal nutritionists Elise Krohn and Valerie Segrest (Krohn and Segrest 2010) indicate that a cup of commonly foraged nettles, chickweed, or dandelion leaves meets or exceeds the USDA-recommended daily allowances of calcium, iron, potassium, vitamins $\mathrm{A}$ and $\mathrm{C}$, thiamin, riboflavin and protein. Moreover, nettles, chickweed and dandelion leaves are more nutrient rich than either spinach or kale. One forager corroborated: "I'm a nutritionist and the nutrient density of these plants ... blows any cultivated plants away."

In addition to nutrients, wild plants and mushrooms have complex medicinal properties urban foragers use to prevent or treat illnesses. Gatherers wildcraft medicines from plants such as echinacea, Oregon grape, feverfew, Saint-John'swort, and others for diverse health applications, including: immune support, digestive health, liver function, cancer prevention, circulatory system and heart health, dermatology and topical healing, breast milk production, emotional and psychological balance, moxibustion (acupuncture), antimicrobial uses, and pain relief. Wild urban medicines complement allopathic (Western) technologies, for example, one wildcrafter recounted,

My daughter was diagnosed with a brain tumor last year and we had wonderful opportunities for the best of what modern medicine can provide from brain surgery to proton radiation treatment. I am so grateful for those things. But she has been supported all along the way by the herbs as well. That's just one more reason why it's really vital to me that these urban foraging opportunities stay available. It really positively impacts the health of my family in a very personal way. It's not a vague idea. It's very specific.

Harvesting local, place-based medicines is a benefit that several gatherers noted. Some shared a view that specific plants grow near people for a purpose: "I've done enough gathering to feel that many plants are here to help us, and that the ones that particularly wish to help us will find a way to be near us." This gatherer also found the health benefits from gathering plants in her immediate environments to be greater than those purchased at herbal apothecaries: "I forage locally because I think it's beneficial." She continued, 
I feel like when you know the plants and you've gathered them yourself, you do heal better. And I think it's more beneficial than just hearing, "Oh, echinacea is good for me. I'm going to buy this bottle in the store because I heard echinacea is good." But it's like, "Do you know echinacea? Do you know what it looks like in the summer? Do you know what it looks like in the winter? Have you gathered the root?" To me, that is an important part of the healing process.

Another gatherer observed that some plant medicines are not available on the commercial market and can only be found through wildcrafting.

Importantly, one forager underscored that being able to gather and make your own medicine is an exercise in asserting autonomy: "Making your own medicine empowers you to be honest. Knowing that you have control. The [government] can tell you what not to buy. They can restrict things. But no one can stop you from taking a walk in a park and finding herbs. No one can do that."

\section{Livelihoods}

While gatherers derive multiple sociocultural benefits, gathering also contributes to household economies through exchanges in formal and informal markets (see Table 4). The diverse economic activities of urban gatherers are best described as small-scale, alternative, and non-market (Emery and Pierce 2005; Gibson-Graham 2008). Of the 58 gatherers interviewed, under half (27) received some income from foraging related activities. None maintained a dedicated commercial business from direct sales of urban NTFPs gathered in Seattle. Three described selling a little extra tree fruit such as Italian plums or figs to a local restaurant on multiple occasions, while two had done so only once. However, several foragers described benefiting economically through indirect and value-added activities. For example, one participant is a professional beekeeper and sells honey from urban-based hives. Four participants are professional chefs who, among other fresh and local ingredients, used wild foraged edibles (e.g. nettles, dandelion greens and rosehips) in their culinary dishes. Another nine participants sold value-added products including herbal remedies and tinctures, soaps, baskets, fine art and sculpture derived from plants gathered in the city. Finally, thirteen participants described having some professional role as an educator, doing hands-on teaching about various aspects of wild plant and mushroom uses; the economic importance of teaching varied from donated time to $70 \%$ of the forager's annual income.

Thirty-five interview participants had been involved in some form of bartering or trading. Often, these exchanges would take place between friends and neighbors, and on occasion with other gatherers, fisherfolk and hunters. One person described trading baskets for dental care. Some foragers traded or shared meals with one another through "soup swaps" and wild food potlucks, exchanges more closely reflecting mutual sharing than bartering. Bartering and trading is mostly informal and non-organized, however, in recent years, neighborhood bartering networks and fairs have emerged throughout Seattle. Other foragers were seeking to create exchange opportunities that work outside of a money economy: "There's a strict barter where you're trying to replace money with a good that you have, or with a knowledge or education piece that you know of, and I'll barter at that level, where it's really an exchange instead of money."

Gift giving and social reciprocity are common among nearly all Seattle foragers. One participant described the important links between foraging, gift giving and social ties: "That's one of the major reasons I do it, because I love giving people food. It's my favorite thing to do." Another gave wild goods as a way to share "my passion and my relationship with plants and hoping that they either want to grow their own food and medicine, or learn how to do this for themselves, or engage more in nature, be more aware of how they walk in the world."

\section{Intangible Sociocultural Values}

Building community and maintaining social ties through the practices of gathering food, making medicine, and exchanging goods are important components of urban gathering. Gatherers share knowledge, products, and time in procuring and processing wild goods. These exchanges are instrumental in opening dialogue between strangers as well as strengthening existing friendships and ties across generations within a
Table 4 Livelihood activities of urban foragers

1. Value added goods or services including: environmental education (13); crafts, arts, herbal remedies (9); wild foods chef (4); and urban honey (1).

\begin{tabular}{|c|c|c|}
\hline Economic Activity & Number of Foragers & $\begin{array}{l}\text { percentages } \\
(n=58)\end{array}$ \\
\hline Harvest for personal use (subsistence) & 58 & 100 \\
\hline Engage in barter or trade (informal market) & 35 & 60 \\
\hline Derive income from wild goods (indirect and direct) & 27 & 47 \\
\hline Derive income from indirect sales ${ }^{1}$ & 27 & 47 \\
\hline Derive income from direct sale of raw goods & 3-only occasionally & 5 \\
\hline
\end{tabular}


family. The social connections and shared activities are part of what constitutes gatherers as a community of practice. Moreover, shared experiences help keep gathering traditions alive.

Gathering holds spiritual and philosophical significance for some practitioners. As one person described it, "Foraging is sort of a spiritual thing. That's the draw to it ... the ceremony in picking, eating, and cleaning together. Getting together with friends and sharing knowledge. Sharing the land and sharing your knowledge of the land, and working together just to sustain yourself and enjoy yourself." For some, there are specific ceremonies involved in the harvest and use of a plant. It's common for gatherers to "honor a plant" through a prayer, a donation, or an intention while harvesting, and then to use it as incense, contribution to an altar, or other spiritual practice.

Connections to plants also often extend to urban foragers' environment and place connections, and active gathering is one way local environmental knowledge is shared and maintained. Foragers described their connections with urban nature in intimate and corporeal terms. These intimate connections motivate stewardship activities for some and otherwise break down urban-nature dualisms. This reflection by a gatherer who described herself as a "wilderness girl who was dragged out of the moss and the rain and placed into the city to dry out" demonstrates the links between gathering and stewardship: "I love the urban environment I live in." She continued,

[Urban nature] is worthy, as worthy of our love and appreciation as wilderness out there, because this once was the same. And if we nurture it, it will nurture us. So I get involved with things like restoration. And part of the restoration is about restoring this place, restoring habitat for wildlife and restoring a place for us to go and be connected and be able to forage and gather and be a part of that. So to me it's all kind of one weave.

When confronted by the possibility that one could not gather in the city for whatever reason, whether it be antigathering regulation, loss of habitat, contamination, or other barriers, many foragers responded in stark terms of deep sadness and defiance, finding the idea unfathomable. The thought of not being able to gather would be devastating. For example one person lamented,

Not being able to go and forage would just be like a loss of wilderness in our souls ... It'd be like nature deprivation basically. If it was taken away from me at this point, I would be just destroyed in a lot of ways. Because my connection to my environment would be severed, and my food would be coming in more plastic and more packaging and stuff like that. It would be an awful thing. I mean, food is not only just nourishment, but a wonder to find, and to search for and be in its environment ... that's kind of the last connection we have to our environment is collecting those things that come along from nature. Yeah, I would be very sad.

For many, gathering is an essential lifeway with no alternative.

\section{Discussion and Conclusions}

In a city where the hunger rate is above $14 \%$, and children, particularly children of color, are disproportionately affected by food insecurity such that nearly one in five do not have enough to eat on a weekly basis, wild foods in the city might play a critical role in addressing hunger (King County 2012). With over 450 species in the city having sociocultural value to foragers and a plant food biomass that is estimated at well over $100,000 \mathrm{lb},{ }^{4}$ we are faced with the paradoxical coexistence of wild food abundance, elevated rates of hunger, and so-called "nature deficit disorder." Additionally, we face growing public health concerns of increasing rates of diabetes and other chronic diseases in part due to lack of access to healthy foods and exercise and to high stress. In urban centers where unequal access to adequate food and health services and changing environments present difficult challenges to well-being, it is increasingly important to examine the linkages between active wild food and medicine practices, local and traditional plant knowledge, and the ability to manage and procure these resources safely.

In this article, we have documented the ways that urban NTFP gathering supports local food and medicinal practices and other dimensions of cultural expression. Selfprovisioning with wild foods and medicines are the two primary reasons people gather plants and mushrooms in Seattle. NTFP harvesting also strengthens urban residents' access to nutrient rich plants while maintaining traditions and social ties, and deepening connections with nature in the city in culturally meaningful ways. Not only does gathering offer positive physical and mental health benefits, but it also is part of a larger set of processes related to food and health sovereignty and justice. Seeking wild foods and medicines in the city can be seen as a way in which foragers assert their rights to the natural resources that support their wild food and health practices. In this light, urban foraging is an alternative to the commercial food economy and institutionalized health care systems dominating cities. Wild foods and medicines are also important sociocultural benefits of urban ecosystems rarely acknowledged by conservation professionals.

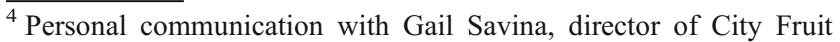
organization
} 
The results of this study raise a number of social justice concerns about city residents' use of and access to products from the urban forest. First, access to natural resources is limited by regulatory codes prohibiting gathering and by vegetation management and conservation regimes on public lands that do not fully recognize foraging as a legitimate practice. These institutional dynamics impede rights to food, wellness, and cultural expression. Second, by ignoring the food and medicine functions of urban ecosystems, gatherers' cultural meanings and values regarding these spaces are also discounted. Finally, the marginalization of this community of practice further limits meaningful participation in urban environmental decision-making. Our work suggests the need for an urban forest justice framework that recognizes the rights of local people to have control over their own culturally appropriate food and health systems, including access to edible and healthful wild resources, participation in decision-making about how these are managed, and the fundamental ways that cultural identities and social relations are embedded in forest systems provisioning wild goods.

Until we begin to see NTFP gathering as an important socio-ecological function of urban forests, the values and practices of gatherers will be ignored. This study offers a first step in "seeing urban gatherers" and "locating their practices" in the urban forest by examining the cultural practices of wild food and medicine gathering in the city, in order to better understand their particular needs, identities, and nature-based cultural expressions as they relate to urban forest justice. Further research is needed to examine the institutional dynamics of property and tenure of urban common goods, the toxicological profiles of urban soils and strategies to avoid risks from gathering urban wild foods and medicines, and finally, the role urban foraging plays in motivating stewardship practices in urban forests.

Acknowledgements We are grateful for the gatherers and research participants. We would like to thank research assistants Lauren Urgenson and Joyce LeCompte-Mastenbrook, as well as Arthur Lee Jacobson, Alissa Allen and Noah Siegel for species identification support, and Leilan Greer for assistance with copy-editing. We thank the two anonymous reviewers. We also thank Ursinus College Institutional Review Board for review of our methods. This work was supported by the USDA Pacific Northwest Research Station and the American Recovery and Reinvestment Act.

\section{References}

Adamson J. (2011). Medicine Food: Critical Environmental Justice Studies, Native North American Literature, and the Movement for Food Sovereignty. Environmental Justice 4.

Adelson, N. (2000). 'Being Alive Well': Health and the Politics of Cree Well-Being. University of Toronto Press, Quebec.
Alberti, M., Marzluff, J. M., Shulenberger, E., Bradley, G., Ryan, C., and Zumbrunnen, C. (2003). Integrating Humans into Ecology: Opportunities and Challenges for Studying Urban Ecosystems. BioScience 53: 1169-1179.

Alkon, A., and Agyeman, J. (2011). Cultivating Food Justice: Race, Class, and Sustainability. MIT Press, Cambridge.

Alkon AH, Mares TM. (2012). Food Sovereignty in US Food Movements: Radical Visions And Neoliberal Constraints. Agriculture and Human Values.

B.C. Food Systems Networking Group on Indigenous Food Sovereignty. No date. http:www.indigenousfoodsystems.org. Accessed 01/04/13.

Balick, M. J., and Lee, R. (2001). Looking within: Urban Ethnomedicine and Ethnobotany. Alternative Therapies in Health and Medicine 7: 114-115.

Barker, P. A. (1986). Fruit Litter From Urban Trees. Journal of Arboriculture 12: 293-298.

Bharucha, Z., and Pretty, J. (2010). The Roles and Values of Wild Foods in Agricultural Systems. Philosophical Transactions of the Royal Society B 365: 2913-2926.

Blaikie, P., and Brookfield, H. (1987). Land Degradation and Society. Methuen, London.

Brosius, J. P., Tsing, A. L., and Charles, Z. (eds.) (2005). Communities and Conservation: Histories and Politics of Community-Based Natural Resource Management. Altamira, Wanut Creek.

Brownlow, A. (2005). An Archaeology of Fear and Environmental Change in Philadelphia. Geoforum 37: 227-245.

Bruyere, J. (2006). Nehinaw (Cree) Socioeconomic, Political and Historical Explanations About the Collective Diabetes Experience. In Indigenous Peoples and Diabetes: Community Empowerment and Wellness. Carolina Academic Press, Durham.

Bryant, R. L., and Bailey, S. (1997). Third World Political Ecology. Routledge, New York.

Byrne, J., and Wolch, J. (2009). Nature, Race, and Parks: Past Research and Future Directions for Geographic Research. Progress in Human Geography 33: 743-765.

Cardinal, N. (2006). The Exclusive City: Identifying, Measuring and Drawing Attention to Urban Aboriginal and Indigenous Experiences in and Urban Context. Cities 23(3): 217-228.

US Census 2010. United States Census, Seattle Demographics.

Ceuterick, M. I. V., Torry, B., and Pieroni, A. (2008). Cross-Cultural Adaptation in Urban Ethnobotany: The Columbian Folk Pharmacopoeia in London. Journal of Ethnopharmacology 120: 342-359.

City of Seattle. (2009). City of Seattle Demographic and Populations Statistics.

Deur, D. (2002). Plant Cultivation on the Northwest Coast: A Reconsideration. Journal of Cultural Geography 19: 9-35.

Dobbs, C., Escobedo, F. J., and Zipperer, W. C. (2011). A Framework for Developing Urban Forest Ecosystem Services and Goods Indicators. Landscape and Urban Planning 99: 196-206.

Donovan, G. H., and Butry, D. T. (2010). Trees in the City: Valuing Street Trees in Portland, Oregon. Landscape and Urban Planning 94: 77-83.

Dooling, S. (2009). Ecological Gentrification: A Research Agenda Exploring Justice in the City. International Journal of Urban and Regional Research 33: 621-639.

Emery, M. R., and Pierce, A. R. (2005). Interrupting the Telos: Locating Subsistence in Contemporary US Forests. Environment and Planning A 37: 981-993.

Emery M, Martin S, Dyke A. (2006). Wild Harvests From Scottish Woodlands: Social, Cultural and Economic Values of Contemporary Non-Timber Forest Products. ed. F Commission. Edinburgh, Scotland, UK.

Food Research and Action Center. (2011). Food Hardship: A Closer Look At Hunger. http://frac.org/wp-content/uploads/2011/03/ food_hardship_report_mar2011.pdf. 
Ford, R. I. (1985). Patterns of Prehistoric Food Production in North America. In Ford, R. I. (ed.), Prehistoric Food Production in North America. Museum of Anthropology, University of Michigan, Ann Arbor.

Garrett S, J. Naas, C. Watterson, T. Henze, S. Keithly, and S. RadkeSproull. (2006). Sound Food Report: Enhancing Seattle's Food System. A Report to the City of Seattle.

Gibson-Graham, J. K. (2008). Diverse Economies: Performative Practices for 'Other Worlds'. Progress in Human Geography 32(5): 613-632.

Grabbatin, B., Hurley, P., and Halfacre, A. (2011). 'I Still Have the Old Tradition': The co-Production of Sweetgrass Basketry and Coastal Development. Geoforum 42(6): 638-649.

Grove, J. M., Cadenasso, M. L., Burch Jr., W. R., Pickett, S. T. A., Schwarz, K., et al. (2006). Data and Methods Comparing Social Structure and Vegetation Structure of Urban Neighborhoods in Baltimore, Maryland. Society and Natural Resources 19: 117-136.

Guthman, J. (2008). Neoliberalism and the Making of Food Politics in California. Geoforum 39: 1171-1183.

Hecht, S., and Cockburn, A. (1990). The Fate of the Forest: Developers, Destroyers, and Defenders of the Amazon. HarperCollins, New York.

Heynen, N. C. (2003). The Scalar Production of Injustice Within the Urban Forest. Antipode 35: 980-998.

Hodges, S., and Bennett, B. C. (2006). The Ethnobotany of Pluchea Carolinensis (Jacq.) G. Don (Asteraceae) in the Botanicas of Miami, Florida. Economic Botany 60: 75-84.

Hull, R. B. I. (1992). Brief Encounters with Urban Forests Produce Moods That Matter. Journal of Arboriculture 18: 322-324.

Jacobson, A. L. (2008). Wild Plants of Greater Seattle. Arthur Lee Jacobson, Seattle.

Jahnige (2002). The Hidden Bounty of the Urban Forest. In Jones, E. T., McLain, R. J., and Weigand, J. (eds.), Nontimber Forest Products in the United States. University Press of Kansas, Lawrence, pp. 96-101.

Jennings V, Gaither CJ, Gragg RS. (2012). Promoting Environmental Justice Through Urban Green Space Access: A Synopsis. Environmental Justice 5

Kaplan, S. (1995). The Restorative Benefits of Nature: Toward an Integrative Framework. Journal of Environmental Psychology 15: $169-182$.

Kassam, K.-A., Karamkhudoeva, M., Ruelle, M., and Baumflek, M. (2010). Medicinal Plant Use and Health Sovereignty: Findings from the Tajik and Afghan Pamirs. Human Ecology 38: 817-829.

King County, (2012). Equity and Social Justice Annual Report. www.kingcounty.gov/equity King County, Seattle WA.

Kinzig AP, Warren P, Martin C, Hope D, Katti M. (2005). The Effects Of Human Socioeconomic Status and Cultural Characteristics on Urban Patterns of Biodiversity. Ecology and Society 10.

Klooster, D. J. (2000). Community Forestry and Tree Theft in Mexico. Resistance, or Complicity in Conservation? Development and Change 31: 281-306

Konijnendijk C. (2008). The Forest and the City: The Cultural Landscape of Urban Woodland. New York, NY: Springer. 245 p $\mathrm{pp}$.

Kosek, J. (2006). Understories: The Political Life of Forests in Northern New Mexico. Duke University Press, Durham.

Krohn, E., and Segrest, V. (2010). Feeding the People, Feeding the Spirit: Revitalizing Northwest Coastal Indian Food Culture. Northwest Indian College, Bellingham.

Kuhnlein, H., and Turner, N. J. (1991). Traditional Plant Foods of Canadian Indigenous Peoples: Nutrition, Botany and Use. Food and Nutrition in History and Anthropology. Vol. 8. Taylor \& Francis, Netherlands

Kuo, F. (2003). The Role of Arboriculture in a Healthy Social Ecology. Journal of Arboriculture 29: 148-155.
Kuo, F. E., and Sullivan, W. C. (2001). Environment and Crime in the Inner City: Does Vegetation Reduce Crime? Environment and Behavior 33: 346-367.

Loring, P. A., and Gerlach, S. C. (2009). Food, Culture, and Human Health in Alaska: An Integrated Health Approach to Food Security. Environmental Policy and Science 12: 466-478.

McLain R, MacFarland K, Brody, L., Buttolph, L.B., Hebert, J., Hurley, P., Gabriel, N., Emery, M., Poe, M., and Charnley, S. (2012a). Gathering in the City: An Annotated Bibliography on Urban Non-Timber Forest Products Gathering. Pacific Northwest Research Station PNW-GTR-849.

McLain, R., Poe, M., Hurley, P. T., and Lecompte-Mastenbrook, J. (2012b). Producing Edible Landscapes in Seattle's Urban Forest. Urban Forestry \& Urban Greening 11: 187-194.

McMichael, P. (2009). A Food Regime Genealogy. Journal of Peasant Studies 36: 139-169.

McPherson, G., Simpson, J. R., Peper, P. J., Maco, S. E., and Xiao, Q. (2005). Municipal Forest Benefits and Costs in Five US Cities. Journal of Forestry 103: 411-416.

Melles S, Glenn S, Martin. K. (2003). Urban Bird Diversity and Landscape Complexity: Species-Environment Associations Along a Multiscale Habitat Gradient. Conservation Ecology 7.

Middleton, E. (2010). A Political Ecology of Healing. Journal of Political, Ecology. 17

Nabhan, G. P. (2006). Renewing Salmon Nation's Food Traditions. Ecotrust, Portland.

Northwest Indian College. n.d. Traditional Plants and Foods Program. http://www.nwic.edu/content/traditional-plants Accessed 01/04/ 13.

Nowack, D. J., Crane, D. E., and Stevens, J. C. (2006). Air Pollution Removal by Urban Trees and Shrubs in the United States. Urban Forestry and Urban Greening 4: 115-123.

OFM. (2010). Estimates and Forecasts. Official April 1 Population Estimates.

Paulson, S., Gezon, L. L., and Watts, M. J. (2005). Politics, Ecologies, Genealogies. In Paulson, S., and Gezon, L. L. (eds.), Political Ecology Across Spaces, Scales, and Social Group. Rutgers University Press, New Brunswick.

Peet, R., Robbins, P., and Watts, M. J. (eds.) (2011). Global Political Ecology. Routledge, New York.

Peluso, N. (1992). Rich Forests, Poor People. University of California Press, Berkeley.

Peluso N. L., and P. Vandergeest. (2001). Genealogies of the Political Forest and Customary Rights in Indonesia, Malaysia, and Thailand. Journal of Asian Studies 61.

Petersen, L. M., Moll, E. J., Collins, R., and Hockings, M. T. (2012). Development of a Compendium of Local, Wild-Harvested Species Used in the Informal Economy Trade, Cape Town, South Africa. Ecology and Society 17(2): 26

Ribot, J. C., and Peluso, N. L. (2003). A Theory of Access. Rural Sociology 68: 153-181.

Robbins, P. (2012). Political Ecology: A Critical Introduction, 2nd ed. Blackwell Publishing, Malden.

Robbins, P., Emery, M., and Rice, J. L. (2008). Gathering in Thoreau's Backyard: Nontimber Forest Product Harvesting as a Practice. Area 40: 265-277.

Rocheleau, D. (2008). Political Ecology in the key of Policy: From Chains of Explanation to Webs of Relation. Geoforum 39: 716727.

Salmón, E. (2012). Eating the Landscape: American Indian Stories of Food, Identity and Resilience. University of Arizona Press, Tuscon.

Samson, C., and Pretty, J. (2006). Environmental and Health Benefits of Hunting Lifestyles and Diets for the Innu of Labrador. Food Policy 31: 528-553.

Sanderson, E. W., and Huron, A. (2011). Conservation in the City. Conservation Biology 25: 421-423. 
Schroeder, R. (1999). Shady Practices: Agroforestry and Gender Politics in The Gambia. University of California Press, Berkeley.

Sikor, T. (2010). Forest Justice: Towards a new Agenda for Research and Practice? Journal of Integrative Environmental Sciences 7(4): $245-250$.

Sikor, T., Stahl, J. (2011). Forests And People: Property, Governance, and Human Rights. Earthscan.

Simpson, J. R. (1998). Urban Forest Impacts on Regional Cooling and Heating Energy use: Sacramento County Case Study. Journal of Arboriculture 24(4): 201-214.

SMC 18.12.070. Seattle Municipal Code. Seattle, WA.

Söderback, I., Söderström, M., and Schälander, E. (2004). Horticultural Therapy: The Healing Garden and Gardening in Rehabilitation Measures at Danderyd Hospital Rehabilitation Clinic, Sweden. Pediatric Rehabilitation 7(4): 245-260.

Stamets, P. (2005). Mycelium Running: How Mushrooms Can Help Save the World. Ten Speed Press, Berkeley.

Terada, T., Yokohari, M., Bolthouse, J., and Tanaka, N. (2010). "Refueling" Satoyama Woodland Restoration in Japan: Enhancing Restoration Practice and Experiences Through Woodfuel Utilization. Nature and Culture 5: 251-276.

Thrush, C. (2007). Native Seattle: Histories from the Crossing-Over Place. University of Washington Press, Seattle.
Turner, N. J. (1995). Food Plants of Coastal First People. UBC Press, British Columbia Canada.

Wehi, P. M., and Wehi, W. L. (2009). Traditional Plant Harvesting in Contemporary Fragmented and Urban Landscapes. Conservation Biology 24: 594-604.

Westphal, L. M. (2003). Urban Greening and Social Benefits: A Study of Empowerment Outcomes. Journal of Arboriculture 29: 137-147.

Whitman, H. (2011). Food Sovereignty: A new Rights Framework for Food and Nature? Environment \& Society: Advances in Research 2: 87-105.

Wilkinson, C. (2000). Messages from Frank's Landing: A Story of Salmon, Treaties, and the Indian Way. University of Washington Press, Seattle.

Wilson, K. (2003). Therapeutic Landscapes and First Nations Peoples: An Exploration of Culture, Health and Place. Health \& Place 9: 83-93.

Wolf, K. L. (2009). Trees Mean Business: City Trees and the Retail Streetscape. Main Street News 263: 1-9.

Xiao, Q., McPherson, E. G., Simpson, J. R., and Ustin, S. L. (1998). Rainfall Interception by Sacramento's Urban Forest. Journal of Arboriculture 24(4): 235-244.

Zerner, C. (1999). People, Plants, and Justice: The Politics of Nature Conservation. Columbia University Press, New York. 